\title{
Examining the Role of Fiscal Policy in Malaysian Stock Market
}

\author{
Hussain Ali Bekhet ${ }^{1} \&$ Nor Salwati bt Othman ${ }^{2}$ \\ ${ }^{1}$ Graduate Business School, College of Graduate Studies, Universiti Tenaga Nasional (UNITEN), Kajang, \\ Selangor, Malaysia \\ ${ }^{2}$ Department of Finance \& Economics, College of Business and Accounting, Universiti Tenaga Nasional \\ (UNITEN), Kajang, Selangor, Malaysia \\ Correspondence: Hussain Ali Bekhet, Graduate Business School, College of Graduate Studies, Universiti Tenaga \\ Nasional (UNITEN), 43000, Selangor, Malaysia. E-mail: profhussain@uniten.edu.my
}

Received: September 26, 2012

Accepted: October 20, 2012 Online Published: November 7, 2012

doi:10.5539/ibr.v5n12p59

URL: http://dx.doi.org/10.5539/ibr.v5n12p59

\begin{abstract}
This paper analyzes the relationship between stock index and macroeconomic policies (fiscal and monetary) using quarterly data for Malaysia for 1999:Q1-2011:Q4. The change in stock index was used as a proxy for financial performance. The co-integration test utilizes to detect the existence of long run relationship between stock index and macroeconomic variables and develops a vector error correction model (VECM) to test the existence of short run relationship (elasticities) among the variables. The findings indicate that there exists long run relationship among stock index, fiscal and monetary tools. This indicates that fiscal and monetary tools play an important role in accelerating financial performance in Malaysia. However, monetary tools can work faster than fiscal tools. This result would give a signal to investors to strategize their investment decision in the short and long run.
\end{abstract}

Keywords: fiscal policy, financial market, stock market, co-integration, causality, Malaysia

\section{Introduction}

The relationship between stock price and macroeconomics variables has been the subject of extensive theoretical and empirical research over the past three decades. However, large numbers of studies have focused on analyzing the macroeconomics effects of monetary variables (interest rate and money supply) and production variables (GDP, industrial production, domestic export and trade balance) [refer to Table 1]. Only a few papers discuss the empirical link between fiscal policy and stock market. In the case of developed countries, there are several studies that investigated the relationship between stock market and fiscal policy such as those of Afonso et al. (2011), Laopodis (2009), and Arin et al. (2009). Even though Afonso et al. (2011) revealed that spending and government revenue have an important effect on asset market in UK; this does not represent a developing country like Malaysia. The finding could be contradicting or vice versa. To the best of our knowledge, there are no studies related to Malaysia stock market and fiscal policy variables. This strengthens the importance of the current study and the value it adds to existing literature. Moreover, there is still a question on whether fiscal policy plays an important role in Malaysia stock market, and on which policy gives the big impact to Malaysia stock market; is it fiscal or monetary policy?

Therefore, in this paper we will analyze the dynamic relationship between stock index and fiscal policy. Monetary variables will also be employed in order to compare the level of sensitivity of Malaysia stock market towards the changes in fiscal and monetary variables. Additionally, this study attempts to evaluate in terms of sensitivity of Malaysia stock market towards the implementation of fiscal and monetary policy and secondly, to investigate the co-integration relationship among stock index, monetary, and fiscal variables.

For policy implications, the finding(s) of this study would help the policy makers or regulatory bodies understand the behavior of the stock market and benefit the information toward achieving monetary goals. The current study will also help investors to proactively strategize their investment decision. Furthermore, this study is useful to researchers and academicians in finding more evidence on the determinants of Malaysia Stock market. 
Table 1. Survey of relationship between stock market and macroeconomic variables

\begin{tabular}{|c|c|c|c|c|c|c|c|c|c|c|c|c|c|}
\hline & \multicolumn{13}{|c|}{ Authors } \\
\hline & & 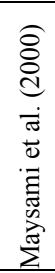 & 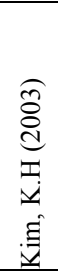 & 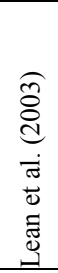 & 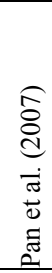 & 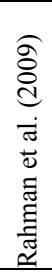 & 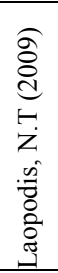 & 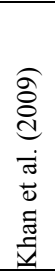 & $\begin{array}{l}\stackrel{0}{0} \\
\stackrel{d}{d} \\
\searrow \\
\tilde{d} \\
\stackrel{0}{0}\end{array}$ & 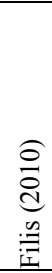 & 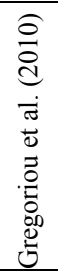 & 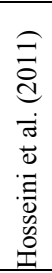 & 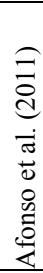 \\
\hline \multirow{19}{*}{ 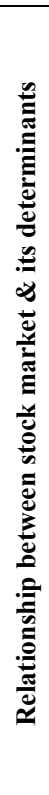 } & Interest rate & $\sqrt{ }$ & $\sqrt{ }$ & & & $\sqrt{ }$ & & $\sqrt{ }$ & & & & & \\
\hline & Inflation & $\sqrt{ }$ & $\sqrt{ }$ & & & & & & & & & $\sqrt{ }$ & \\
\hline & Money supply & $\sqrt{ }$ & & & & $\sqrt{ }$ & $\sqrt{ }$ & & & & & $\sqrt{ }$ & \\
\hline & Domestic Export & $\sqrt{ }$ & & & & & & & & & & & \\
\hline & Industrial production & $\sqrt{ }$ & $\sqrt{ }$ & & & $\sqrt{ }$ & $\sqrt{ }$ & & & $\sqrt{ }$ & & $\sqrt{ }$ & \\
\hline & Exchange rate & & $\sqrt{ }$ & $\sqrt{ }$ & $\sqrt{ }$ & $\sqrt{ }$ & & $\sqrt{ }$ & & & & & \\
\hline & CPI & & & & & & $\sqrt{ }$ & $\sqrt{ }$ & & $\sqrt{ }$ & & & \\
\hline & Treasury note & & & & & & $\sqrt{ }$ & & & & & & \\
\hline & AAA corporate bond & & & & & & $\sqrt{ }$ & & & & & & \\
\hline & Federal Government fund & & & & & & $\sqrt{ }$ & & & & & & \\
\hline & Trade balance & & & & & & & $\sqrt{ }$ & & & & & \\
\hline & GDP & & & & & & & & $\sqrt{ }$ & & & & $\sqrt{ }$ \\
\hline & Demographic structure & & & & & & & & $\sqrt{ }$ & & & & \\
\hline & Oil price (crude) & & & & & & & & & $\sqrt{ }$ & & $\sqrt{ }$ & \\
\hline & Good price & & & & & & & & & & $\sqrt{ }$ & & \\
\hline & Government spending & & & & & & & & & & & & \\
\hline & Government revenue & & & & & & & & & & & & $\sqrt{ }$ \\
\hline & Unemployment rate & & & & & & & & & & & & $\sqrt{ }$ \\
\hline & Housing price & & & & & & & & & & & & $\sqrt{ }$ \\
\hline
\end{tabular}

The rest of the paper is structured as follows: Section 2 and 3 present the background of stock market and fiscal policy in Malaysia respectively. Section 4 reviews the past literature. Section 5 defines data sources and variables. Section 6 describes the methodology of the study. Section 7 analyses the results. And finally, section 8 discusses the conclusion and policy implications.

\section{Bursa Malaysia, Stock Market and Stock Index}

The role of Bursa Malaysia, stock market and stock index is like bread and butter. Bursa Malaysia is an exchange holding company and was incorporated in April 2004. It offers the exchange-related services such as trading, clearing settlement and depository services. Presently, it is one of the largest bourses in Asia and has expended it services by offering a wide range of investment choices to local industries and worldwide as well. The performance of Bursa Malaysia is believed to effect Malaysia capital market and economic growth. In the first quarter of the 2011, Bursa Malaysia had shown a strong performance, through an increase in the profit after tax and minority interest at 44 percent which is at RM 40.5 million compared to RM 28.1 million for the corresponding quarter last year (www.bursamalaysia.com). Stock market refers to the place where the businesses of buying and selling stock occur. In Malaysia, Bursa Malaysia is an organized market place where these transactions happen under strict rules, regulation and guidelines.

Meanwhile, stock index represents the price of many different stocks from various industries. Also, it is an indicator for the investor to measure the performance of a group of stock. Positive stock index indicates the positive performance of financial market and vise versa. From January 2000 - Jan 2010, Malaysia stock index showed the up and down trend quite often. In November 2007, stock index was at the highest level which was at RM 1396.98 and it was at the lowest level in 2001 and 2008 which were at RM572.88 and RM863.61 respectively [see figure 1]. This reduction was due to economic crisis in the USA. Previous research suggests that there is a closer relationship between the performance of financial market and economic growth (Baharumshah et al., 2002; Wongbangpo et al., 2002; Silvia \& Iqbal, 2011). Others confirm that anything happening to financial market will influence the variation in economic activities, demand for real money, interest rate and subsequently, the value of domestic currency (Ibrahim \& Wan Yusoff, 2001). In fact, the stock market is often considered as the primary 
indicator of a country's economic strength and development. Accordingly, the present research focuses on identifying the role of government economic policy in determining the pattern of Malaysia's stock index.

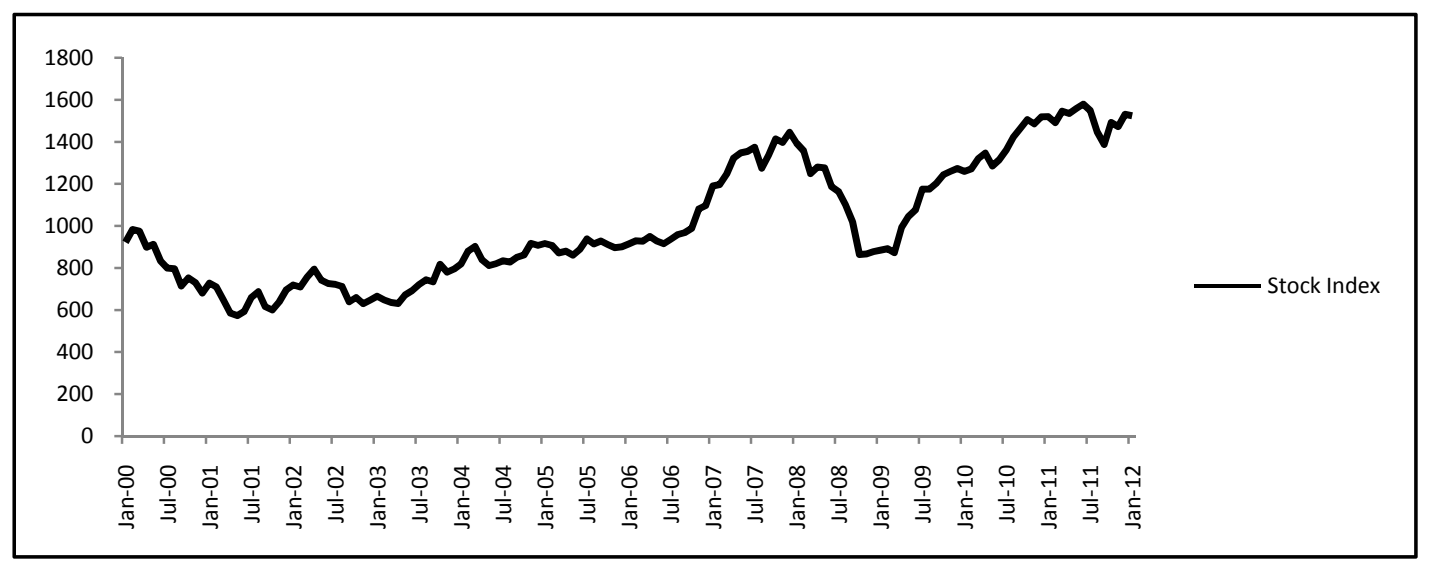

Figure 1. Malaysian Stock market index (in RM)

Source: Yahoo Finance.

\section{Fiscal Policy in Malaysia}

In recent years, people have become aware of fiscal policy and its impact on other macroeconomic indicators and performance. By practicing the fiscal policy, the government decides how much to spend, what to spend, what to spend for and how to finance its spending (Abel et al., 2011). Hubbard and O'Brien (2010) defined fiscal policy as a change in federal taxes and purchases that are intended to achieve macroeconomics policy objectives.Federal government expenditure in Malaysia was allocated for 2 major purposes namely, operation purposes and development purposes. The rationale for allocating the budget for operation purposes is to upgrade and improve productivity as well as to impede long term economic growth potential. The largest component of operating expenditure is emoluments, subsidies, supplies and services. The factor contributing to higher allocation for emoluments is to accommodate the improved scheme of service for the police as well as the amendment to the salary scheme of medical and dental lecturers in public higher education institutions (Economic Report, Ministry of Finance 2010-2011). Subsidies is second top operation expenditure. Its trend has increased over the years starting from 2006 onwards and the impact is closely linked to the world commodity prices, particularly oil (Economic Report 2010/2011; Ministry of Finance). The reason for improving subsidies is to reduce the burden of society especially to the poor and disadvantaged group.

On the other hand, the rationale for allocating the budget for development purposes is to upgrade rural basic infrastructure, urban transport, low income household and other social services. These expenditure purposes have a significant role in sustaining growth momentum and positive economic transformation. Figure 2(a) shows the growth rate of government operating and development expenditure for the 1980-2011 period. The government development expenditure growth is faster than the operating expenditure which is 7.1 percent compare to 8.5 percent for development expenditure.

The main source of the federal government revenue is the tax collection and non-tax revenue to finance its expenditures and to improve growth prospect of the country as well. There are several types of tax and non-tax revenues such as service tax, sales tax, excise tax, export duties, import duties, income tax and non-tax revenue (license, permit and investment income). The income tax is the major tax revenue in Malaysia (Economic Report, Ministry of Finance 2010-2011).

Malaysia has been experiencing fiscal deficit over the years. In 2007, the deficit was recorded at RM23764 million and it was increased to RM36553 million and RM47943 million in year 2008 and 2009 respectively [See Figure 2(a)-2(b)]. Even though this amount was getting bigger throughout the years, as compared to GDP growth, it was reported at 7 percent of GDP in 2009 and was decreasing to 5.6 percent in 2010 (Bernama, May 13 2010). This figure indicates that the growth of Malaysia's economicis relatively faster that the growth of fiscal deficit. As consequences of government injection, it would affect the aggregate demand, government capital formation and labour incentive and finally in the long run it would stimulate economic growth. In this paper we are going to investigate the role of fiscal policy (government expenditure and revenue) toward the performance of economic activities and financial performance and then to compare their contribution with monetary policy. 


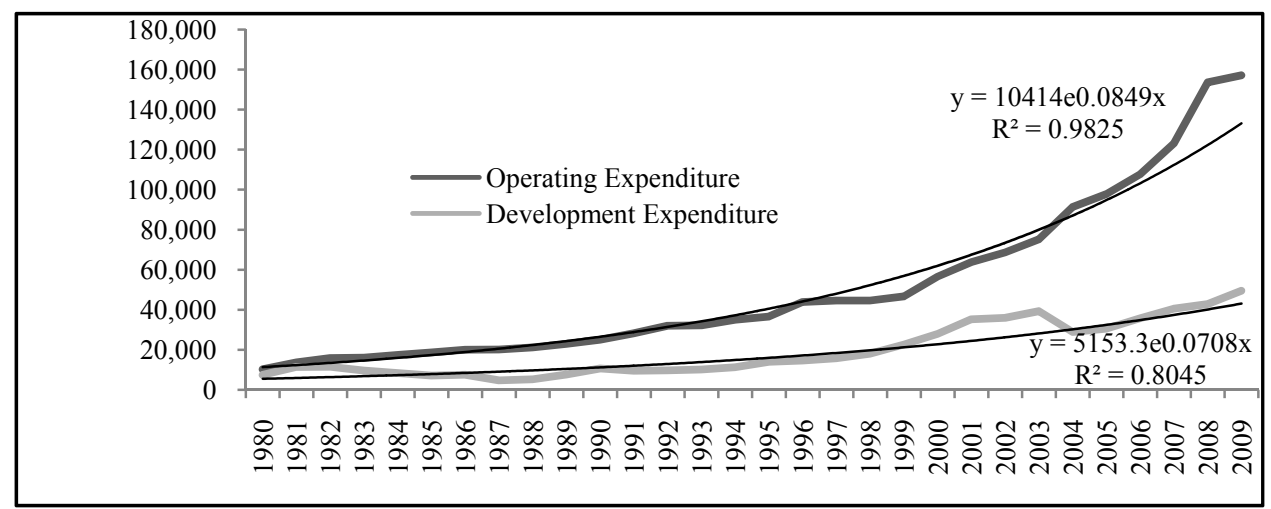

Figure 2(a). Government expenditure (in RM million)

Source: Ministry Of Finance.

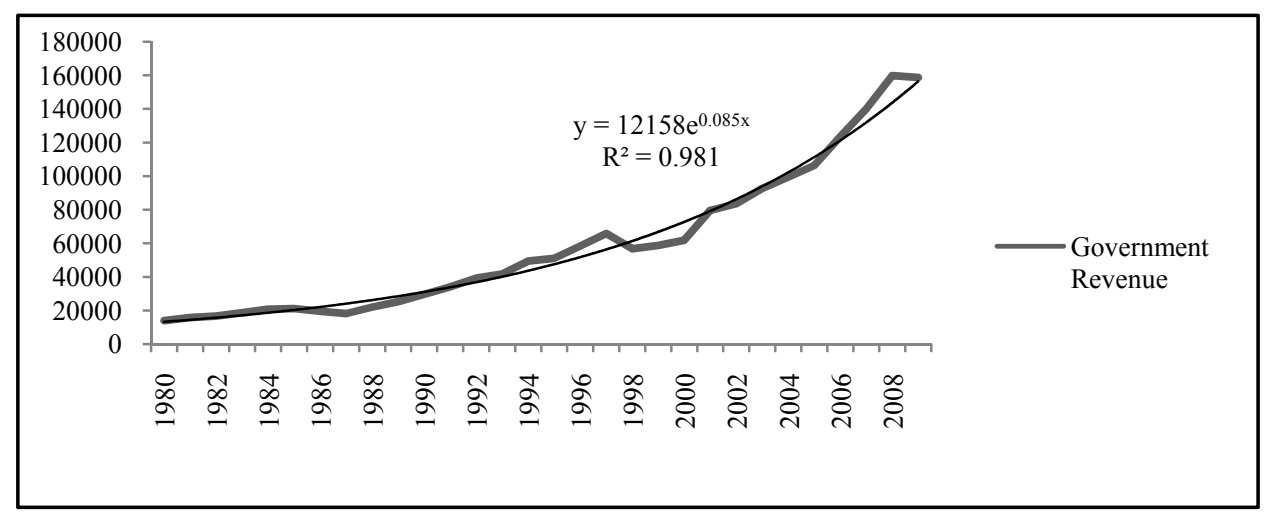

Figure 2(b). Government revenue (in RM million)

Source: Ministry Of Finance.

\section{Literature Review}

A large amount of literature strives to shed light on the relationship between stock market and macroeconomics variables, such as exchange rate, industrial production, money supply, inflation and interest rate. However, the findings were found to be mixed. Some of macroeconomics variables show consistent results and some of the findings are conflicted.

Many studies have endeavoured the existence of co-integrating relationship between stock market and interest rate (For example, Maysami et al., 2000; Wongbanggpo et al., 2002; Kim, 2003; Baharumshah et al., 2002; Rahmanet al., 2009). All these studies also found the co-integration relationship between the aforementioned variables and the findings show the consistent relationship between stock market and interest rate.

Theoretically, interest rate and money is likely to affect stock market index. In this regard, many studies show that money supply has a dynamic effect on stock market index (For example, see Maysami et al., 2000; Ibrahim \& Wan Yusoff, 2001; Rahman et al., 2009; Hosseini et al., 2011). Most of them report a long run relationship between stock market index and money supply.

In the case of the impact of industrial production, Kim (2003) investigated the relationship between stock market and industrial production. He validates that stock price is positively related to industrial production. This result is consistent with Rahman et al. (2009) and Hosseini et al. (2011). However, Filis (2010) showed that there was no relationship between industrial production and stock market. Maysami et al. (2000) and Laopodis (2009) have shown the insignificant results.

Other studies explored the relationship between stock market and exchange rate (Such as, Lean et al., 2003; Kim, 2003; Pan et al., 2007; Rahman et al., 2009). Furthermore, these findings have shown that there is no consensus relationship between them. For USA data, Kim (2003) tracked down that stock price is negatively related to exchange rate while in different location (major Asian countries). Lean et al., (2003) viewed no co-integration relationship between stock price and exchange rate except for the Philippine and Malaysia and it is only happening 
before financial crisis. Using data after the financial crisis, Lean et al. (2003) unearthed relationship between stock price and exchange rate in Korea, while other Asian countries show insignificant result. However, using data at a different time frame which is from 1988-1998, Pan et al. (2007) noticed that there was a relationship between same variables for Hong Kong, Japan and Thailand before and during financial crisis.

Beside the aforementioned variables, there are more macroeconomic variables that have been tested by previous researchers such as CPI (inflation), GDP and oil price. Kim (2003) and Filis (2010) indicated a long run relationship between CPI and stock market index. On the other hand, Filis (2010) and Hosseini et al. (2010) revealed that oil price has a relationship with stock market index.

Most of studies have focused on analyzing the macroeconomic effects of monetary variables (interest rate and money supply) and production variables (GDP, industrial production, domestic export and trade balance. Some of these researches confirmed that there is a relationship between fiscal policy and stock market (Arin et al., 2009; Afonso et al., 2011; Silvia \& Iqbal, 2011). The results are consistent among these studies and revealed the connection between fiscal variables and stock market. However, these findings represent developed countries and there is still a question for developing countries like Malaysia, regarding the empirical relationship between fiscal variables and stock market index.

\section{Data Sources and Basic Variables}

In the current paper, Stock index (S), government operating expenditure (GO), government development expenditure (GD), tax revenue (T), interest rate (r) and money supply (M) are employed. The sources of these data are Department of Statistics (DOS), World Bankand Yahoo Finance@ Bursa Malaysia. The purpose of combining these 4 sources is to ensure the consistency of this timeseries. The timeseries in this study is a quarterly data ranging from 1999(Q1) to 2011(Q4); this will make the total observation equals to 51.

Stock index (S) is the dependent variable which is applied to measure the financial performance of a country. This data was obtained from Yahoo finance and was measured in Ringgit Malaysia (RM). Since the original data was in monthly basis, itwas transformed into quarterly form in order to ensure consistency with other timeseries data.These data were in constant value, where the year 2000 was used as a base year. Likewise, the monetary variables were obtained from DOS and were measured in percentage. Money supply was extracted from M2 and measured in RM millions. All variables presented in logarith forms because this would help to induce stationarity (Narayan \& Smyth, 2005) and to obtainelasticities (Hill et al., 2008). Below is the definition of variables in this study.

$L S=\log$ stock index indicates the growth rate of stock index.

$L G=\log$ government expenditure indicates growth rate of government expenditure.

(Goverment expenditure $=$ operating expenditure + development expenditure)

$L T=\log$ tax revenue indicates growth rate of tax revenue.

$L M=\log M 2$ indicates growth rate of money supply.

$\mathrm{Lr}=\log$ interest rate indicates growth rate of interest rate.

Preliminary analysis was performed to ensure non-violation of the assumptions of normality, homogeneity, linearity and multi-collinearity by using E-views package version 7.1.

\section{Methodology}

Theoretically, both Keynesian and neoclassical economists provided varieties of policies and tools of government intervention, which are broadly grouped into fiscal and monetary (Usman et al., 2011). The choice of a policy or tools depends on how relatively effective it is, in achieving the set of macroeconomic objectives based on theory and evidence. In practice, both policies are implemented to achieve sustainable economic growth. In one hand, monetary tools ( $\mathrm{r}$ and $\mathrm{M}$ ) can spur economic growth by providing incentive for saving to ensure a large pool of investment fund that is needed to sustain growth (Hubbard \& O' Brien, 2011). By using the expansionary monetary policy, increasing the $\mathrm{M}$ and decreasing $\mathrm{T}$ are expected to increase GDP. In other words, there is a negative correlation between $r$ and GDP, and positive correlation between M and GDP.

However, fiscal tools can spur economic growth by increasing government expenditure or cutting taxes. This means that there is a negative correlation between $\mathrm{T}$ and GDP, and positive correlation between government expenditures (GO and GD) and GDP.

Meanwhile, previous researchers found a relationship between financial performance and economic growth (Baharumshah et al., 2002; Wongbangpoet al., 2002; Silvia \& Iqbal, 2011). In conjunction with the above 
scenario, we investigate the role of fiscal and monetary tools in sustaining financial performance (stock index).Thus, in this paper stock index (S) can be expressed in general as a function of fiscal tools (GO, GD and T) and monetary tools (M and r). Also, stock index (S) is the dependent variable and the rest are the independent variables. The function of stock index (S) can be expressed in Equation 1.

$$
S_{t}=f\left(G_{t}, T_{t}, M_{t}, r_{t}\right)
$$

In order to achieve the objective of the study, it is important to choose an appropriate technique otherwise the result will be inconsistent. Then, the modeling strategy will be as follows:

a. The first step of the analysis is a stationary test for each variable (after transforming into logarithmic form). ADF and $\mathrm{PP}$ tests at level $I(0)$ used for stationary test [see Equation 2].

$$
y_{t}=\emptyset y_{t-1}+\varepsilon_{t}
$$

Where; $y_{t}$ represents the variables of the study and it will be run individually. Besides, there is not stationary if the variables contains unit root $@ \emptyset=1$. However, if $\emptyset \neq 1$, the data is stationary. Therefore, If the data is not stationary, we have to proceed with stationary test at first difference $I(1)$. If the data still is not stationary at first deference, we proceed stationary test at second difference. Usually, the macroeconomics data achieved stationary at first difference or second difference (Tang, 2008; Bekhet \& Othman, 2011).

b. The second step is, generally, to explore the connection between dependent and independent variables and to assess sensitivity (elasticity). So, we adopt a double log model. This model is also known as constant elasticity model. It can be done only if all value of dependent and independent variables are in positive value (Hill, et al., 2008) [see Equation 3].

$$
\begin{gathered}
\log S_{t}=\beta_{0}+\beta_{1} \log G_{t}-\beta_{2} \log T_{t}+\beta_{3} \log M_{t}-\beta_{4} \log r_{t}+U_{t} \\
\Delta U_{t}=\rho U_{t-1}+\varepsilon_{t}
\end{gathered}
$$

Where; $\beta_{1}, \beta_{2}, \beta_{3}$ and $\beta_{4}$, represent the level of sensitivity of stock index towards the changes in independent variables. The greater $\beta_{1}, \beta_{2}, \beta_{3}$ and $\beta_{4}$, indicate higher sensitivity. $\beta_{2}$ and $\beta_{4}$ have a negative value because we expect the tax and interest rate to have a negative relationship with financial performance (stock index). However, other variables have a positive relationship with financial performance (stock index). The $U_{t}$ is an error term. It represents a "storage bin" for unobservable or unimportant factor affecting the stock index (Hill et al., 2008).

c. Co-integration test: The co-integration can be captured by analyzing the stationarity of the residual calculated by the sub-equation 3. If the residual is stationary, this indicates that there is long run equilibrium among variables (Vogelvang, 2005) and all the variables are accepted by macroeconomics theory to analyze the sensitivity of the stock index. If the variables are not co-integrated at level we ought to test for co-integration at first and then second difference until they are co-integrated. The decision whether to reject or not depends on the value of ADF statistic value for residual term. If this value is smaller than the critical value of ADF test we have to reject the $\mathrm{H}_{0}$ which means that there is no co-integration (Volgelvang, 2005). This procedure is crucial because the sensitivity is valid only if the variables have the same order of integration. ADF and PP tests for co-integration were used to investigate the degree of integration.

d. The previous procedures are vital in determining the appropriate model (VAR, VECM, \&ARDL) to assess the direction of causality among the variables. There are 3 possible outcomes: first outcome is the variables stationary but not co-integrated, second outcome is the variables stationary and co-integrated and finally, the variables stationary and co-integrated but the sample size is not large enough (usually less $<30$ case). For the first option, most researchers used VAR model (unrestricted VAR). For the second option, they applied VECM (restricted VAR) (Jobert \& Karanfil, 2007) and for the third option, it employed ARDL model. However, if some variables are not stationary, we may use ARDL as well (Halicioglu, 2011).

Assuming that all variables are co-integrated, we use VECM to identify the nature of the long run equilibrium relationship using the 2 step procedure of Engle and Granger. In the first step, we estimate the long run model for equation 3 in order to obtain the estimated error [See Equation 3, after this we call it ect]. In the second step, we estimate short run and long run interaction with ect as shows below [see Equation 4]:

$$
\Delta l S_{t}=\propto_{0}+\sum_{i=1} \propto_{1} \Delta l S_{t-i}+\sum_{i=1} \propto_{2} \Delta l G_{t-i}+\sum_{i=1} \propto_{3} \Delta l T_{t-i}+\sum_{i=1} \propto_{4} \Delta l M_{t-i}+\sum_{i=1} \propto_{5} \Delta l r_{t-i}+\propto_{6} e c t_{t-i}
$$

Where IS, IG, IT, IM and Ir represent the natural log of stock index, government expenditure, tax, money supply and interest rate respectively, whileect represents error correction term. The VECM enables us to estimate the long run and short run relationships (elasticities) on one model. The coefficients $\alpha_{i}(i=1, \ldots, 5)$ indicate the short run relationships if the valuesare not equal to zero. However, if these coefficients are equal to zero, this indicates that there are no short run relationships among respective variables. Furthermore the coefficient $\alpha_{6}$ indicates the 
long run relationship if the coefficient is not equal to zero and vice versa.

\section{Results Analysis}

Before conducting the co-integration and granger causality test, it is important to determine the stability of the time series data using ADF and PP tests. The results affirm that all variables (stock index, government expenditures, taxes, money supply and interest rate) contain a unit root and were found to be non-stationary at level. However, after the first different, all variables were found to be stationary at 5 percent [see Table 2]. Therefore, it can be concluded that they are stationary at first different and this results is in line with earlier studies (Tang, 2008; Bekhet \& Othman, 2011).

Table 2. Unit root test

\begin{tabular}{llllll}
\hline \multirow{2}{*}{$\begin{array}{l}\text { Variables } \\
\text { used }\end{array}$} & ADF test & & \multicolumn{2}{l}{ PP test } \\
\cline { 2 - 3 } \cline { 5 - 6 } DLG & ADF statistic & Critical Value & & P.P statistic & Critical Value \\
DLM & -26.65 & -2.93 & -33.80 & -2.92 \\
DLr & -5.28 & -2.92 & -5.29 & -2.92 \\
DLS & -4.37 & -2.92 & -4.36 & -2.92 \\
DLT & -8.40 & -2.92 & -8.63 & -2.92 \\
\hline
\end{tabular}

Note: *All varibles are significant at 5 percent.

Source: Output of Eviews Package, Version 7.1.

According to Engle and Granger (1987), if all variables are stationary, equation 3 can be estimated by Ordinary Least Square, OLS (see Equation 5) and if the resulting residuals are stationary at level $I(0)$ then all variables used are confirmed to be co-integrated. Table 3 confirmed that the variables of this study are co-integrated. Through co-integration test, we found the existence of long run relationship among variables. Furthermore, this result is consistent with earlier findings (Maysami et al., 2000; Kim, 2003; Rahman et al., 2009; Wongbanggpo et al., 2002; Baharumshah et al., 2002).

Equation [5] revealed the long run elasticities or sensitivity of stock price toward the changes in $\mathrm{LG}_{\mathrm{t}}, \mathrm{LT}_{\mathrm{t}}, \mathrm{LM}_{\mathrm{t}}, \mathrm{Lr}_{\mathrm{t}}$ variables. The results validate that stock price was inelastic (not sensitive) towards the changes in interest rate which represents the monetary tools.

$$
\begin{array}{rccccc}
L S_{t} & =-1.13 & -0.11 L G_{t} & +0.09 L T_{t} & +0.63 L M_{t} & -0.10 L r_{t} \\
\text { Sig. } & =(0.51) & (0.39) & (0.64) & (0.00) & (0.72) \\
R^{2} & =0.77 & \text { F Stat }=39.53 & \text { Sig. }=(0.00) & &
\end{array}
$$

Table 3. Co-Integration Test

\begin{tabular}{llll}
\hline Variable & ADF statistic & Critical value at 5\% level & Result \\
\hline Residual $(\varepsilon)$ & -3.49 & -2.92 & $\begin{array}{l}\text { Reject } \mathrm{H}_{0} \text { : No co-integration @ } \\
\mathrm{I}(1)\end{array}$ \\
\hline
\end{tabular}

Note: *Significant level at 5 percent.

Source: Output of Eviews Package, Version 7.1.

In order to detect the short run relationships (elasticities) between the explainer's variables and stock market, we apply the VECM. This model enables us to detect the short run and long run relationships (elasticities) at the same time. Equation 6 reports the result of the VECM.

$$
\begin{array}{rlcccccc}
\Delta L S_{t} & =0.04 & +0.02 \Delta L S_{t-1} & +0.06 \Delta L G_{t-1} & -0.05 \Delta L T_{t-1} & -0.04 \Delta L M_{t} & +1.43 \Delta L r_{t-1} & -0.45 e c t_{t-1} \\
\text { Sig. } & =(0.24) & (0.92) & (0.46) & (0.68) & (0.97) & (0.047) & (0.00) \\
R^{2} & =0.28, & \text { F Stat }=2.68 & (0.03) & D / W=1.94 & & &
\end{array}
$$

The results of VECM indicate that interest rate can influence stock price in the short run and long run, while other fiscal variables unable to influence stock price in the short run. They only influence the stock price in the long run. This result was inconsistent with Ibrahim and WanYusoff (2001) due to different methodology and period of study. 


\section{Conclusion and Policy Implication}

The current paper analyzes the relationship between stock index and macroeconomic policies (fiscal and monetary) using quarterly data for Malaysia for 1999:Q1-2011:Q4. The change in stock index was used as a proxy for financial performance. This study used the co-integration test to detect the existence of long run relationship and develop a vector error correction model (VECM) to test the existence of short run relationship (Elasticities). The empirical findings indicate that there exists a long run relationship among stock index, fiscal and monetary tools. This result indicates that fiscal and monetary tools play an important role in accelerating financial performance in Malaysia. However, monetary tools can work faster compared to fiscal tools. This finding would give a signal to the investor to strategize their investment decisions in the short and long run.

\section{References}

Abel, A. B., Bernanke, B. S., \& Croushore, D. (2010). Macroeconomics (7th ed.). USA: Pearson International.

Afonso, A., \& Sousa, R. M. (2011). What Are The Effects of Fiscal Policy on Asset Markets? Economic Modeling, 28(4), 1871-1890. http://dx.doi.org/10.1016/j.econmod.2011.03.018

Arin, K. P., Mamun, A., \& Purushothman, N. (2009). The effects of Tax Policy on Financial markets: G3 Evidence. Review of Financial Economics, 18(4), 33-46. http://dx.doi.org/10.1016/j.rfe.2008.05.001

Bae, Y. (2010). Stock Price and Demographic Structure: A Co-integration Approach. Economics Letters, 107(3), 341-344. http://dx.doi.org/10.1016/j.econlet.2010.02.017

Baharumshah, A. Z., Masih, A. M., \& Azali, M. (2002). The Stock market and The Ringgit Exchange Rate: A Note. Japan and The World Economy, 14, 471-486. http://dx.doi.org/10.1016/S0922-1425(02)00019-1

Bekhet, H. A., \& Othman, N. S. (2011). Causality analysis among electricity consumption, consumer expenditure, gross domestic product (GDP) and foreign direct investment (FDI): Case study of Malaysia. Journal of Economics and International Finance, 3(4), 228-235.

Bernama. (2010, May, 13). Bernama. Malaysia.

Economic Report 2010/2011. (n.d.). Ministry of Finance, Malaysia. Retrieved from http://www.treasury.gov.my $>$ ECONOMY $>$ Economic Report.

Filis, G. (2010). Macro economy, Stock market and Oil Prices: Do meaningful relationships exist Among Their Cyclical Fluctuations? Energy Economics, 32, 877-886. http://dx.doi.org/10.1016/j.eneco.2010.03.010

Gregoriou, A., \& Kontonikas, A. (2010). The Long run Relationship Between Stock Prices and Goods Price: Evidence From Panel Co-integration. International Finance Market, Inst. And Money, 20, 166-176. http://dx.doi.org/10.1016/j.intfin.2009.12.002

Gujarati, D. N., \& Porter, D. C. (2009). Basic Econometrics (5th ed.). USA: McGraw-Hill International Edition

Halicioglu, F. (2011). A dynamic Econometric Study of Income, Energy and Exports in Turkey. Energy, 36, 3348-3354. http://dx.doi.org/10.1016/j.energy.2011.03.031

Hill, R. C., Griffith, W. E., \& Lim, G. C. (2008). Principles of Econometrics (3rd ed.). USA: Wiley,

Hosseini, S. M., Ahmad, Z., \& Lai, Y. W. (2011). The Role of Macroeconomics Variables on Stock Market Index in China and India. International Journal of Economics and Finance, 3(6), 233-243. http://dx.doi.org/10.5539/ijef.v3n6p233

Hubbarrd, R. G., \& O’ Brien, A. P. (2010). Macroeconomics (3rd ed.). USA, Pearson International Edition.

Ibrahim, M. H., \& Wan Yusoff, W. S. (2001). Macroeconomics Variables, Exchange rate and Stock Price: A Malaysian Perspective. IIUM Journal of Economics and management, 9(2), 141-163.

Jobert, T., \& Karanfil, F. (2007). Sectoral Energy Consumption by Source and Economic Growth in Turkey. Energy Policy, 35, 5447-5456. http://dx.doi.org/10.1016/j.enpol.2007.05.008

Kim, K. H. (2003). Dollar Exchange Rate and stock Price: Evidence From multivariate Co-integration and Error Correction model. Review of Financial economics, 12(3), 301-313. http://dx.doi.org/10.1016/S1058-3300(03)00026-0

Laopodis, N. T. (2009). Fiscal Policy and Stock Market Efficiency: Evidence For The United State. The quarterly Review of Economics and finance, 49(2), 633-650. http://dx.doi.org/10.1016/j.qref.2007.10.004

Lean, H. H., Halim, M., \& Wong, W. K. (2003). Bivariate Causality between Exchange Rates and Stock Prices on Major Asian Countries. Work paper, 1-41. 
Maysami, R. C., \& Koh, T. S. (2000). A Vector Error Correction Model of The Singapore stock Market. $\begin{array}{lllll}\text { International Review of Economics and } & \text { Finance, 9, }\end{array}$ http://dx.doi.org/10.1016/S1059-0560(99)00042-8

Narayan, P. K., \& Smyth, R. (2005). Electricity Consumption, Employment and Real Income in Australia Evidence from Multivariate Granger Causality Test. Energy Policy, 33, 1109-1116. http://dx.doi.org/10.1016/j.enpol.2003.11.010

Pan, M. S., Fok, R. C., \& Liu, Y. A. (2007). Dynamic Linkages Between Exchange Rates and Stock Prices: Evidence From East Asian Markets. International review of Economics and Finance, 16, 503-520. http://dx.doi.org/10.1016/j.iref.2005.09.003

Rahman, A., Sidek, N. Z., \& Tafri, F. H. (2009). Macroeconomics Determinants of Malaysia Stock Market. African Journal of Business Management, 3(3), 95-106.

Silvia, J., \& Iqbal, A. (2011). Monetary Policy, Fiscal Policy, and Confidence. International Journal of Economics and Finance, 3(4), 22-35. http://dx.doi.org/10.5539/ijef.v3n4p22

Stock, J. H., \& Watson, M. W. (2007). Introduction to Econometrics (2nd ed.). USA: Pearson International Edition.

Studenmund, A. H. (2011). Using Econometrics: A Practical Guide (6th ed.). USA: Pearson International Edition.

Tang, C. F. (2008). A re-examination of the relationship between electricity consumption and economic growth in Malaysia. Energy Policy, 36, 307-3085. http://dx.doi.org/10.1016/j.enpol.2008.04.026

Usman, A., Mobolaji, H. I., Kilishi, A. A., Yaru, M. A., \& Yakubu, T. A. (2011). Public Expenditure and Economic Growth In Nigeria. Asian Economic and Financial Review, 1(3), 104-113.

Vogelvang, B. (2005). Econometrics: Theory and applications with EViews (1st ed.). UK: Prentice Hall.

Wongbangpo, P., \& Sharma, S. C. (2002). Stock Market and macroeconomics Fundamental Dynamic Interactions: ASEAN-5 Countries. Journal of Asian Economics, 13, 27-51. http://dx.doi.org/10.1016/S1049-0078(01)00111-7

Zhu, H. M., Li, S. F., \& Yu, K. (2011). Crude Oil Shocks and Stock Markets: A panel Threshold Co-integration Approach. Energy Economics, 33(5), 987-994. http://dx.doi.org/10.1016/j.eneco.2011.07.002 